\title{
A ClpB Chaperone Knockout Mutant of Mesorhizobium ciceri Shows a Delay in the Root Nodulation of Chickpea Plants
}

\author{
Clarisse Brígido,, ${ }^{1}$ Marta Robledo, ${ }^{2}$ Esther Menéndez, ${ }^{2}$ Pedro F. Mateos, ${ }^{2}$ and Solange Oliveira ${ }^{1}$ \\ ${ }^{1}$ Laboratório de Microbiologia do Solo, ICAAM (Instituto de Ciências Agrárias e Ambientais Mediterrânicas), Universidade \\ de Évora, Apartado 94, 7002-554 Évora, Portugal; ${ }^{2}$ Departamento de Microbiología y Genética, Centro Hispano Luso de \\ Investigaciones Agrarias; Universidad de Salamanca, Salamanca, 37185, España
}

Submitted 30 May 2012. Accepted 31 July 2012.

\begin{abstract}
Several molecular chaperones are known to be involved in bacteria stress response. To investigate the role of chaperone $\mathrm{ClpB}$ in rhizobia stress tolerance as well as in the rhizobiaplant symbiosis process, the $\operatorname{clpB}$ gene from a chickpea microsymbiont, strain Mesorhizobium ciceri LMS-1, was identified and a knockout mutant was obtained. The ClpB knockout mutant was tested to several abiotic stresses, showing that it was unable to grow after a heat shock and it was more sensitive to acid shock than the wild-type strain. A plant-growth assay performed to evaluate the symbiotic performance of the $c l p B$ mutant showed a higher proportion of ineffective root nodules obtained with the mutant than with the wild-type strain. Nodulation kinetics analysis showed a 6- to 8-day delay in nodule appearance in plants inoculated with the $\Delta c l p B$ mutant. Analysis of nodC gene expression showed lower levels of transcript in the $\Delta c l p B$ mutant strain. Analysis of histological sections of nodules formed by the $\operatorname{clp} B$ mutant showed that most of the nodules presented a low number of bacteroids. No differences in the root infection abilities of green fluorescent proteintagged $\operatorname{clp} B$ mutant and wild-type strains were detected. To our knowledge, this is the first study that presents evidence of the involvement of the chaperone ClpB from rhizobia in the symbiotic nodulation process.
\end{abstract}

Severe stresses result in extensive protein denaturation and aggregation. However, bacteria have developed molecular mechanisms, including chaperones and potentially destructive proteases, to deal with the stress effects, ensuring cell survival. Molecular chaperones are protective systems within the cell to prevent protein aggregation, assist refolding, and mediate degradation of misfolded proteins (Hartl 1996). Molecular chaperones like ClpB, DnaK, GroEL, and small heat-shock proteins, such as $\mathrm{IbpA}$ and $\mathrm{IbpB}$, are known to participate in bacterial stress response and tolerance to various stress conditions (Hartl et al. 2011).

The Escherichia coli $\mathrm{ClpB}$ and its homologue in yeast, Hsp104, are essential for cell survival during extreme heat stress (Sanchez and Lindquist 1990; Squires et al. 1991), due to its ability to solubilize and reactivate protein aggregates that were previously viewed as dead-ended products in the life of

Nucleotide and amino acid sequence data are available in the GenBank database under accession number JQ779034.

Corresponding author: Solange Oliveira; E-mail: ismo@uevora.pt proteins (Parsell et al. 1994; Weibezahn et al. 2005). Moreover, $\mathrm{ClpB}$ seems to be involved in virulence in Listeria monocytogenes (Chastanet et al. 2004) and in other stresses, such as ethanol and acid stresses in Brucella suis (Ekaza et al. 2001) and osmotic stress in Bifidobacterium breve UCC (Ventura et al. 2005).

Hsp104/ClpB belongs to the Hsp100/Clp superfamily of ATPase associated with various cellular activities (AAA+) (Dougan et al. 2002; Neuwald et al. 1999), which form large hexameric ring structures in an ATP-dependent manner (Lee et al. 2003; Wang et al. 2001; Zolkiewski et al. 1999). Hsp100/Clp superfamily proteins contain central components of the protein quality-control system that degrade or disaggregate unfolded and aggregated proteins (Maurizi and Xia 2004; Mogk et al. 2008; Sauer et al. 2004).

The bacterial $\mathrm{ClpB}$ monomer contains an $\mathrm{N}$-terminal domain and two AAA+ nucleotide-binding domains (NBD) separated by a coiled-coil middle-domain (M-domain) (Barnett et al. 2000; DeSantis and Shorter 2012; Doyle and Wickner 2009). Several studies indicate that the M-domain is essential for the chaperone activity (Barnett et al. 2005; Kedzierska et al. 2003; Lee et al. 2005; Mogk et al. 2003; Schirmer et al. 2004). Protein disaggregation by $\mathrm{ClpB}$ in vitro requires the collaboration of a second ATP-dependent molecular chaperone, DnaK, to promote the solubilization and reactivation of proteins that misfold and aggregate following heat shock (Goloubinoff et al. 1999; Motohashi et al. 1999; Zolkiewski 1999). This cooperation is essential for the ability of cells to survive transient extreme stress conditions (Squires et al. 1991).

Biological nitrogen fixation is of extreme importance in both agronomic and environmental terms, as it is an alternative to the use of chemical nitrogen fertilizers. Rhizobia are soil bacteria able to establish symbiotic relationships with legumes and can convert nitrogen into ammonia within the plant root nodules. In general, two main developmental processes are required for the formation of symbiotic $\mathrm{N}_{2}$-fixing nodules, bacterial infection and nodule organogenesis (Gage 2004; Oldroyd and Downie 2008). These processes must be coordinated in both spatial and temporal manners to ensure nodule formation at the site of bacterial infection (Oldroyd and Downie 2008).

Early events in the symbiosis process, such as molecular signaling, rhizobia attachment, root-hair curling, infectionthread formation, and nodule initiation, are particularly sensitive to high temperatures, salinity, acidity, and other environmental stresses (Hungria and Stacey 1997; Hungria and Vargas 2000; Zhang and Smith 1996). Furthermore, during the infection process, rhizobia also have to deal with adverse conditions within 
the host cells and with the plant innate immunity that induce physiological stress responses and may interfere with the symbiosis (Soto et al. 2009). These stresses may negatively affect the microsymbiont in free-living conditions as well as during the symbiotic relationship, thus leading to an ineffective nitrogen fixation (Zahran 1999).

Transcriptomic and proteomic analyses of rhizobia in symbiosis with host plants suggest the involvement of chaperones in this process (Djordjevic et al. 2003; Karunakaran et al. 2009; Pessi et al. 2007; Tsukada et al. 2009). These approaches provide a global view on putative genes involved in symbiosis, but further strategies such as gene knockout are required to confirm the involvement of a specific gene. In order to investigate the potential role of the chaperone $\mathrm{ClpB}$ in the stress tolerance of mesorhizobia in free-living conditions and in symbiosis with chickpea plants, the $\operatorname{clp} B$ gene of the strain Mesorhizobium ciceri LMS-1 was deleted and the mutant was characterized.

\section{RESULTS}

Analysis of the clpB gene sequence from $M$. ciceri LMS-1.

The complete nucleotide sequence $(2,607 \mathrm{bp})$ corresponding to the $\operatorname{clpB}$ gene of $M$. ciceri LMS-1 was determined after polymerase chain reaction (PCR) amplification and was compared with those from other bacteria (Fig. 1). The predicted aminoacid sequence corresponds to a protein of approximately 96 $\mathrm{kDa}$. The amino-acid alignment with characterized prokaryotic ClpB proteins showed that the $M$. ciceri LMS-1 ClpB possesses an N-terminal domain, two nucleotide-biding regions (NBD1 and NBD2), and a coiled-coil M-domain inserted into NBD1 (Fig. 1), corresponding to the typical domains of the bacterial ClpB subfamily.

The predicted amino-acid sequence displays a high degree of similarity to predicted and experimentally proven ClpB proteins from a wide variety of organisms. As expected, the comparative analysis showed that the most similar protein (100\% identity) to

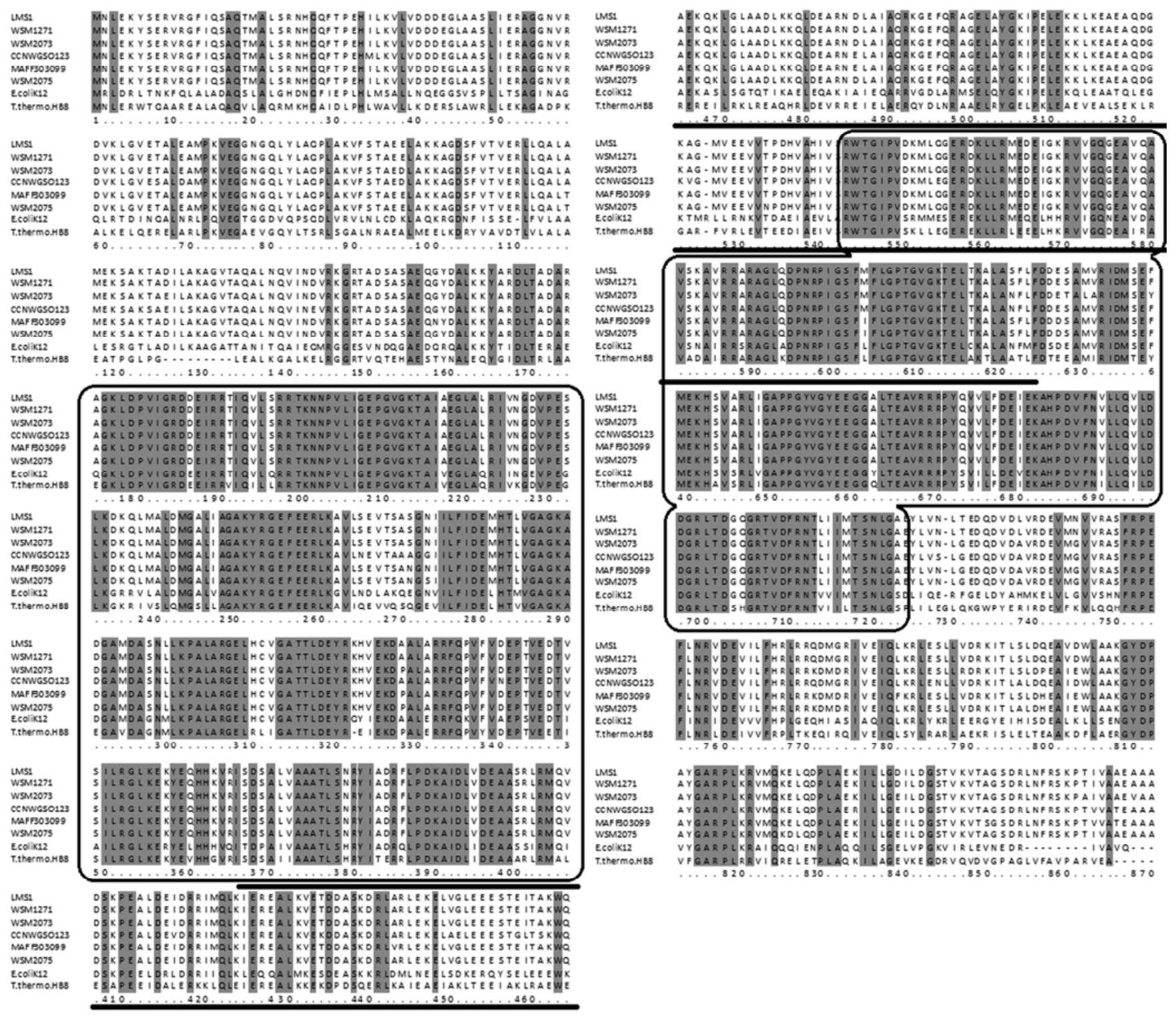

Fig. 1. Alignment of $\mathrm{ClpB}$ protein amino-acid sequences from bacteria belonging to genus Mesorhizobium, Escherichia coli, and Thermus thermophilus. The conserved residues between all ClpB proteins are indicated in gray columns. LMS-1 = M. ciceri LMS-1 (predicted ClpB); WSM1271 = M. ciceri bv. biserrulae WSM1271 (E8TAM5); WSM2073 = M. australicum WSM2073 (G4JW53); CCNWGS0123 = M. amorphae CCNWGS0123 (G6YIV4); MAFF303099 = Mesorhizobium sp. strain MAFF303099 (Q98G96); WSM2075 = M. opportunistum WSM2075 (F7Y492); E.coliK12 = E. coli strain K12 (P63284); T.termo.HB8 = Thermus thermophilus HB8 (Q9RA63). The regions containing the two ATP-binding domains (ATP-1 and ATP-2) are boxed. Amino acids underlined correspond to the BamHI-Eco47III deletion fragment in M. ciceri LMS-1. 
the predicted $M$. ciceri LMS-1 ClpB was the putative ClpB protein from $M$. ciceri bv. biserrulae WSM1271 (accession number E8TAM5). Nevertheless, identity levels $>50 \%$ were observed between the predicted $M$. ciceri LMS-1 ClpB amino-acid sequence and the $\mathrm{ClpB}$ amino-acid sequences from unrelated bacteria such as E. coli $(58.1 \%)$ and Thermus thermophilus (57.2\%). Moreover, the predicted ClpB sequence from M. ciceri LMS-1 shared high similarity $(>67 \%)$ with the predicted ClpB from bacteria belonging to the $\alpha$-Proteobacteria class, especially in the regions corresponding to the nucleotide binding domains.

\section{Confirmation of the $\Delta c l p B$ knockout mutant construction.}

Deletion of an internal fragment of $675 \mathrm{nt}$ that encodes the Mdomain and the initial sequence of NBD2 within the $\operatorname{clp} B$ gene from $M$. ciceri LMS-1 was performed (Table 1; Fig. 1). The truncated $\operatorname{clpB}$ gene fragment was cloned in the mobilizable suicidal plasmid pK18mobsacB (Schafer et al. 1994) and was transferred to $M$. ciceri LMS- 1 . To confirm the allele replacement after plasmid integration at the desired site of the $M$. ciceri LMS-1 genome, total DNA HindIII-digested samples from wild-type and mutant strains were analyzed by Southern hybridization. A single band of about $2,800 \mathrm{bp}$ was detected in the wild-type strain, indicating that $\operatorname{clp} B$ is a single copy gene in the $M$. ciceri LMS-1 genome (Fig. 2). In contrast, a shorter band with approximately $2,100 \mathrm{bp}$ was detected in the DNA from the $\operatorname{clp} B$ knockout mutant strain, confirming the disruption of the $\operatorname{clp} B$ gene. Furthermore, the absence of $\mathrm{ClpB}$ protein using total proteins from the $\triangle c l p B$ mutant strain was confirmed by immunoblotting assay. On the other hand, Southern hybridization of DNA from the complemented strain showed a band similar to the one obtained with the wild-type strain (Fig. 2).

In order to evaluate the effect of the loss of function of the $\mathrm{ClpB}$ chaperone in stress tolerance and symbiosis, wild-type, mutant, and complemented strains were further tested under stress conditions and during symbiotic interaction with chickpea plants.

\section{$\Delta c l p B$ mutant phenotype under environmental stresses.}

To characterize the phenotype of the ClpB mutant strain, designated as $M$. ciceri LMS-1 $\Delta \operatorname{clpB}$, its growth was evaluated in liquid medium under several conditions, namely, heat, cold, acidity, and salinity stresses. To evaluate the phenotype under different stresses, strains were subjected to both shock and continuous stress conditions (Fig. 3).

No significant differences between the growth rates of the complemented and the wild-type strains under the different conditions were found (data not shown).

In control conditions $\left(28^{\circ} \mathrm{C}, \mathrm{pH} 7 ; 0 \% \mathrm{NaCl}\right), M$. ciceri LMS-1 $\Delta c l p B$ showed a similar growth curve to the wild-type strain (Fig. 3A).
Under heat stress $\left(37^{\circ} \mathrm{C}\right.$ for $\left.54 \mathrm{~h}\right)$, the $\Delta c l p B$ mutant showed a lower growth rate when compared with the wild-type (Fig. $3 \mathrm{~B}$ ), suggesting the involvement of the $\mathrm{ClpB}$ in the adaptation to heat stress. To further determine whether ClpB is important for thermotolerance, the strains were subjected to different heat-shock conditions, namely $45^{\circ} \mathrm{C}$ for $1 \mathrm{~h}$ and $48^{\circ} \mathrm{C}$ for 15 min, followed by growth at control temperature $\left(28^{\circ} \mathrm{C}, 54 \mathrm{~h}\right)$. In both experiments, the wild-type strain showed ability to grow after heat shocks, while the $\Delta c \operatorname{cl} B$ mutant was not able to grow (Fig. 3C and D). Evaluation of growth after a heat shock of $50^{\circ} \mathrm{C}$ for $5 \mathrm{~min}$ showed similar results (data not shown). However, under cold temperatures, no difference was observed between the $\Delta \operatorname{lp} B$ mutant and the wild-type $M$. ciceri LMS-1 strain (data not shown).

Taking into account these results, the production of $\mathrm{ClpB}$ protein in the wild-type strain $M$. ciceri LMS-1 after heat shocks $\left(45^{\circ} \mathrm{C}, 1 \mathrm{~h} ; 50^{\circ} \mathrm{C}, 5 \mathrm{~min}\right)$ was evaluated. Total proteins from the wild-type strain grown under control conditions and after heat shocks were extracted, and $\mathrm{ClpB}$ was detected by immunoblotting assay. A protein with the expected molecular mass $( \pm 96 \mathrm{kDa})$ was found in all conditions (Fig. 4, lanes 1 to $3)$. However, a higher amount of the $\mathrm{ClpB}$ protein was detected in $M$. ciceri LMS-1 cells submitted to heat shock in comparison with cells grown under control conditions, supporting its involvement in heat-shock response. As expected, no band was detected in the $\Delta c l p B$ mutant strain, confirming the ClpB absence in the mutant strain (Fig. 4, lanes 4 to 6).

To investigate the involvement of the $\mathrm{ClpB}$ chaperone in acid tolerance, the wild-type and mutant strains were submitted to different acid conditions. Both strains were grown under $\mathrm{pH} 5$ for $54 \mathrm{~h}$ and were also submitted to a $\mathrm{pH} 3$ shock for $1 \mathrm{~h}$ and were then grown at $\mathrm{pH} 7$ or $\mathrm{pH} 5$ for $54 \mathrm{~h}$. No differences were observed between $\Delta c l p B$ mutant and wild-type strains when grown at $\mathrm{pH} 5$ for $54 \mathrm{~h}$ or when submitted to a $\mathrm{pH} 3$ shift and then grown at $\mathrm{pH} 7$ (data not shown). In contrast, when the cells were subjected to an acid shock $(\mathrm{pH} 3)$ and then grown at $\mathrm{pH}$,

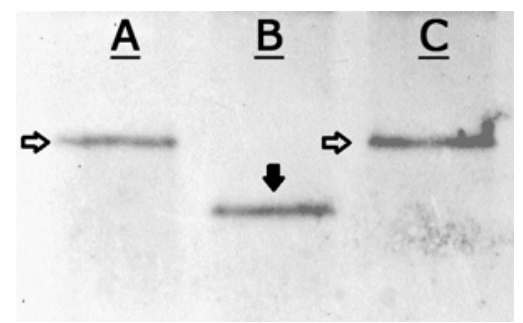

Fig. 2. Southern hybridization of total DNA from A, Mesorhizobium ciceri LMS-1 B, $\Delta c l p B$ mutant, and $\mathbf{C}$, complemented strain digested with HindIII restriction enzyme. Open arrows indicate a band of approximately $2,800 \mathrm{bp}$; closed arrow indicates a band of about $2,100 \mathrm{bp}$.

Table 1. Plasmids and strains used in the present study

\begin{tabular}{|c|c|c|}
\hline Strains and plasmids & Description $^{a}$ & Source or reference \\
\hline \multicolumn{3}{|l|}{ Mesorhizobium ciceri } \\
\hline LMS-1 & Wild-type $\mathrm{Nod}^{+} \mathrm{FiX}{ }^{+}$ & Nascimento et al. 2012 \\
\hline LMS- $1 \Delta \mathrm{clpB}$ & Derivative from LMS-1 $c l p B^{-}$ & This study \\
\hline LMS- $1 c \operatorname{lp} B+$ & Derivative of LMS- 1 clpB reintroduced & This study \\
\hline \multicolumn{3}{|l|}{ Escherichia coli } \\
\hline DH5 $\alpha$ & Host for cloning and triparental conjugation & Sambrook and Russel 2001 \\
\hline JM109 & Host for cloning & Promega Corp., Madison, WI, U.S.A. \\
\hline MT616 & Host containing the helper plasmid used for triparental conjugation & Finan et al. 1986 \\
\hline \multicolumn{3}{|c|}{ (1) } \\
\hline pGEM-T easy & $\mathrm{Amp}^{\mathrm{r}}, \mathrm{M} 13$ ori $\mathrm{pBR} 322$ ori, linear T overhangs vector & Promega Corp. \\
\hline pRK2013 & Helper plasmid for mobilization with replicon ColE1; $\mathrm{Km}^{\mathrm{r}}$ tra & Ditta et al. 1980 \\
\hline pK18mobsacB & plasmid suicide; $\mathrm{Km}^{\mathrm{r}} ; s a c B^{s}$ & Schafer et al., 1994 \\
\hline pMRGFP & pBBR1MCS-2 derivative containing the $g f p$ gene constitutively expressed; $\mathrm{Km}^{\mathrm{r}}$ & Garcia-Fraile et al. 2012 \\
\hline pRK600 & Helper plasmid; pRK2013 npt::Tn9, $\mathrm{Cm}^{\mathrm{r}}$ & Finan et al. 1986 \\
\hline
\end{tabular}

${ }^{\mathrm{a}} \mathrm{Km}^{\mathrm{r}}, \mathrm{Amp}^{\mathrm{r}}$, and $\mathrm{Cm}^{\mathrm{r}}$ indicate resistance to kanamycine, ampicilin, and chloramphenicol, respectively. 
a lower growth rate was observed with the $\Delta c l p B$ mutant strain when compared with the wild-type strain (Fig. 3 E), suggesting the involvement of the $\mathrm{ClpB}$ chaperone in acid tolerance.

The wild-type $M$. ciceri LMS- 1 and $\Delta c l p B$ mutant strains were also tested to salt stress. At continuous growth with $1.5 \%$ $\mathrm{NaCl}$, no difference between growth of $\Delta c \operatorname{lpB}$ mutant and the wild-type strain was observed (data not shown). Furthermore, no differences in growth were observed between strains after a salt shock followed by growth in control conditions (data not shown). Unexpectedly, after a salt shock (5\% $\mathrm{NaCl}$ for $1 \mathrm{~h})$ followed by growth with $1.5 \% \mathrm{NaCl}$ for $54 \mathrm{~h}$, the $\Delta \operatorname{clpB}$ mutant growth was two times higher than the wild-type growth (Fig. 3F).

To examine the involvement of the $\mathrm{ClpB}$ chaperone in the chickpea-Mesorhizobium symbiosis, the symbiotic performance

\section{Evaluation of the symbiotic performance of the $\triangle c l p B$ mutant strain.}

of the $\Delta \operatorname{clp} B$ mutant strain was evaluated. A plant-growth assay was performed in a plant-growth chamber, using vermiculite as substrate. The chickpea plants were harvested eight weeks after inoculation and several parameters were measured (Table 2 ). The shoot and root dry weights of chickpea plants inoculated with the $\Delta \operatorname{clpB}$ mutant strain were lower compared with the ones obtained from plants inoculated with the wild-type strain. However, these differences were not statistically significant. Although no differences in the total number of nodules formed per plant by either strain were obtained, differences in the nodule development were observed. The oxygen-binding plant protein leghemoglobin, which protects the oxygen-labile nitrogenase, accumulates gradually in the host tissue and the nodule becomes pink to bright red (Fisher 1994). Concomitantly, the absence of this protein results in small and white, ineffective nodules (Ott et al. 2005). Despite both strains being able to form pink-colored nodules, the number of white- or pinkcolored nodules induced by each strain was different (Table 2).
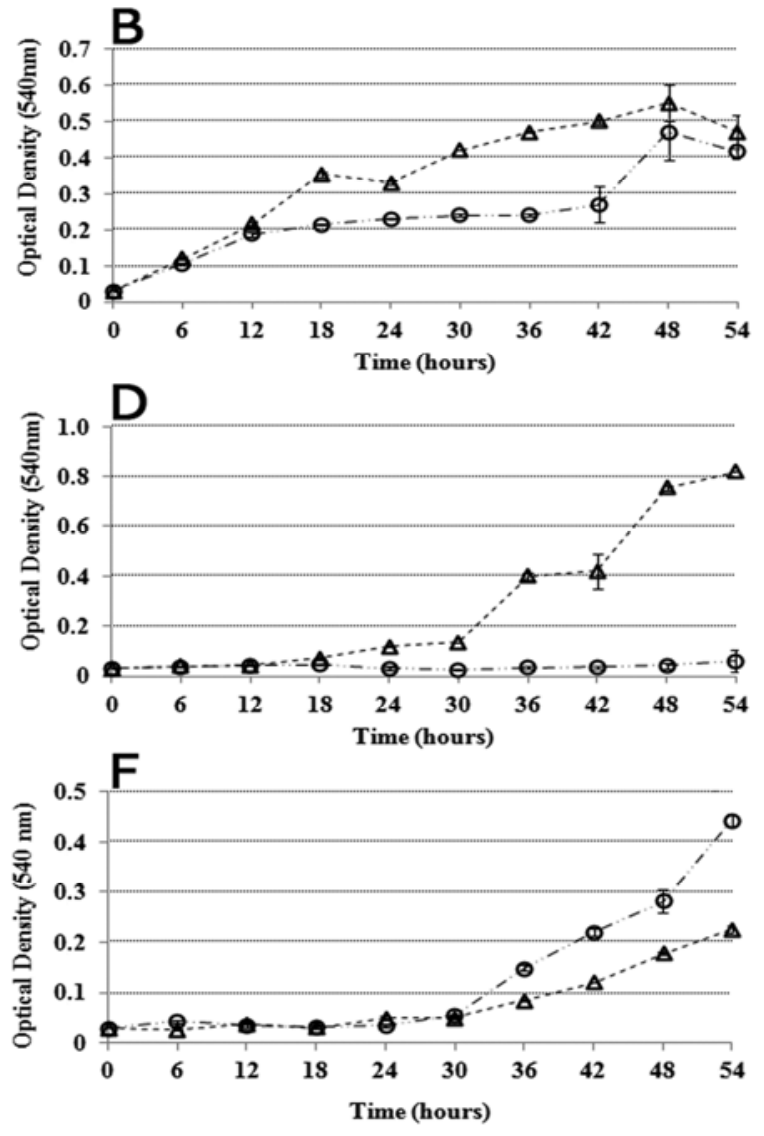

\begin{tabular}{lr}
\hline Stress/shock treatments & $\Delta c l p B$ mutant phenotype \\
\hline $15^{\circ} \mathrm{C}$ for $54 \mathrm{~h}$ & No difference \\
$37^{\circ} \mathrm{C}$ for $54 \mathrm{~h}$ & Higher sensitivity \\
$\mathrm{pH} 5$ for $54 \mathrm{~h}$ & No difference \\
$1.5 \% \mathrm{NaCl}$ for $54 \mathrm{~h}$ & No difference \\
Heat shock $\left(45^{\circ} \mathrm{C}, 1 \mathrm{~h} ; 48^{\circ} \mathrm{C}, 15 \mathrm{~min} ; 50^{\circ} \mathrm{C}, 5 \mathrm{~min}\right)$ & No growth \\
Cold shock $\left(4^{\circ} \mathrm{C}, 1 \mathrm{~h}\right)$ & No difference \\
Salt shock $\left(5^{\circ} \mathrm{NaCl}, 1 \mathrm{~h}\right)$ & No difference \\
Salt shock followed by growth with $1.5 \% \mathrm{NaCl}$ for $54 \mathrm{~h}$ & Higher tolerance \\
Acid shock (pH3, $1 \mathrm{~h})$ & No difference \\
Acid shock followed by growth with pH 5 for $54 \mathrm{~h}$ & Higher sensitivity \\
\hline
\end{tabular}

Fig. 3. Growth curves of wild-type (triangles) and $\Delta c l p B$ mutant (circles) strains under different conditions during $54 \mathrm{~h}$. $\mathbf{A}$, Control conditions: $28^{\circ} \mathrm{C}, 0 \% \mathrm{NaCl}$, $\mathrm{pH}$ 7. B, Growth curves under heat stress at $37^{\circ} \mathrm{C}$. C, Growth curves after a heat shock of $45^{\circ} \mathrm{C}$ for $1 \mathrm{~h}$. D, Growth curves after a heat shock of $48^{\circ} \mathrm{C}$ for 15 min. E, Growth curves under $\mathrm{pH} 5$ after a shift of $\mathrm{pH} 3$ for $1 \mathrm{~h}$. F, Growth curves under salt stress after a salt shock of $5 \% \mathrm{NaCl}$ for $1 \mathrm{~h}$. Data represents the mean and standard deviation of three independent biological replicates. The table summarizes the stress and shock conditions and the effects in the $\Delta c l p B$ mutant. 
From the total number of nodules formed by the wild-type, $84.5 \%$ were fully pink effective nodules, whereas only $61.2 \%$ of the total number of nodules induced by the $\Delta \operatorname{clpB}$ mutant were effective nodules. The number of small and white, ineffective nodules produced by the $\Delta \operatorname{clp} B$ mutant strain was significantly higher compared with those formed by the wild-type, suggesting that the development of nodules induced by the $\triangle c l p B$ mutant strain may be altered. Due to the higher proportion of small nodules, a lower nodule dry weight as well as a lower average weight per nodule was obtained in plants inoculated with the $\Delta \operatorname{clp} B$ mutant strain (Table 2).

The $\Delta c l p B$ mutant shows a delay in nodule development.

In order to determine in which step of the symbiosis process the ClpB is involved, further studies were conducted. A hydroponic plant assay was performed to compare the nodulation kinetics of the $\Delta c l p B$ mutant and wild-type strains. After 10 days of inoculation, the chickpea plants inoculated with the $M$. ciceri LMS-1 showed the first nodules (Fig. 5A). A significant increase in the number of nodules was observed in the first two weeks after the appearance of nodules, and the number of nodules stabilized 30 days after inoculation. On the other hand, the first nodules formed by the $\Delta \operatorname{clp} B$ mutant appeared 16 to 18 days after inoculation, with a 6- to 8-day delay compared with the wild-type strain. The increase in the number of nodules was slower than with the wild-type strain. However, 35 days after inoculation, a similar number of nodules was observed in plants inoculated with either strain. In spite of the similar total number of nodules per plant after 35 days of inoculation, the number of effective nodules was significantly lower in plants inoculated with the $\triangle \operatorname{clpB}$ mutant strain compared with those formed by the wild-type strain $(21 \pm 4$ pink nodules formed by $\triangle c l p B$ mutant strain versus $35 \pm 5$ pink nodules induced by wild-type strain).

To compare the level of expression of the nodulation (nod) genes in the wild-type and in the $\Delta \operatorname{clpB}$ strains, analysis of nodC gene expression was performed by semiquantitative reverse transcription (RT)-PCR. Compared with the wild-type strain, the $\Delta \operatorname{lp} B$ mutant displayed lower levels of nodC transcript, particularly under the heat-shock condition (Fig. 5B). The lower level of nod gene expression can account for the delay observed in root nodulation by the mutant strain (Fig. 5A).

To investigate potential differences in the nodule formation and development induced by $\Delta c l p B$ mutant and wild-type

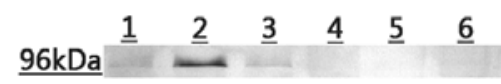

Fig. 4. Western blot analysis of ClpB production levels with polyclonal antibody against Escherichia coli ClpB (1:500). Total protein lysates (15 $\mu \mathrm{g}$ per lane) were obtained from wild-type (lanes 1 to 3 ) and $\Delta c l p B$ mutant (lanes 4 to 6) strains under control and heat-shock conditions. Control conditions $\left(28^{\circ} \mathrm{C}\right)$ (lanes 1 and 4 ), heat-shock conditions: $45^{\circ} \mathrm{C}$ for $1 \mathrm{~h}$ (lane 2 and 5) and $50^{\circ} \mathrm{C}$ for 5 min (lanes 3 and 6). strains, nodules obtained 25 days after inoculation in the hydroponic plant assay were collected. Histological sections of nodules induced by either strain were compared. The main differences observed between the nodules formed by either strain were the size (Fig. 6A to C) and color. The majority of the nodules formed by the $\Delta \operatorname{clp} B$ mutant strain were smaller than the ones formed by the wild-type strain. All nodules induced by the wild-type strain showed the characteristic zones, namely meristematic, invasion, and fixation zones (Fig. 6A). The senescent zone was not visible in any of the nodules analyzed. In contrast, the fixation zone in the majority of the nodules formed by the $\triangle c l p B$ mutant strain showed scarce content in bacteroids. Indeed, the nodules formed by the $\Delta \operatorname{clp} B$ mutant strain contain a

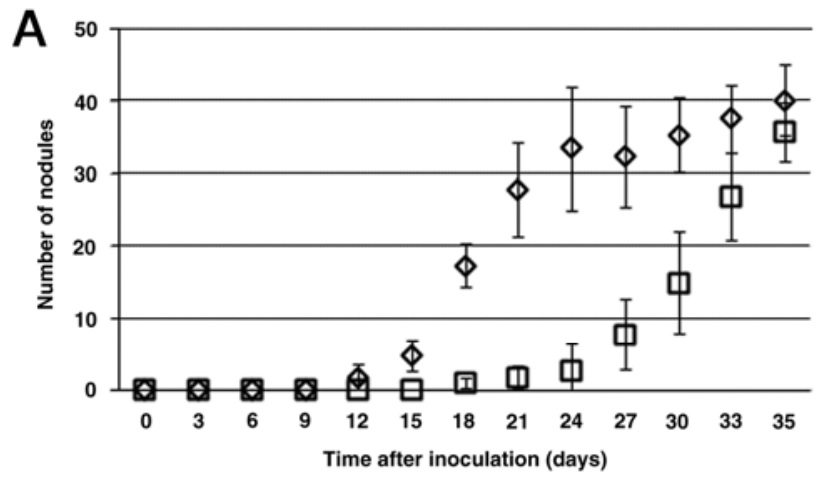

B

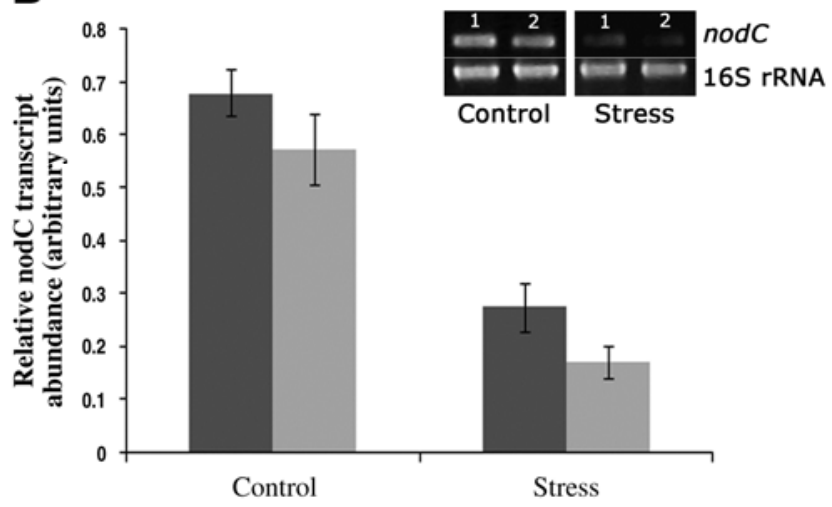

Fig. 5. A, Nodulation kinetics of chickpea plants inoculated with either wildtype (diamonds) or $\Delta c l p B$ mutant (squares) strains during 35 days after inoculation. Each point represents the mean of five plants per treatment. Standard deviation is represented by bars on each data point. B, Analysis of nodC gene expression by semiquantitative reverse transcription-polymerase chain reaction during control and heat-shock conditions in Mesorhizobium ciceri LMS-1 (lane 1, dark gray bars) and $\triangle c l p B$ mutant (lane 2, light gray bars) strains, after 6-h treatment with chickpea root exudates. Relative nodC transcript abundance was normalized against $16 \mathrm{~S}$ rRNA. Data are the means \pm standard deviation of three independent biological replicates.

Table 2. Symbiotic performance in chickpea plants after inoculation with wild-type LMS-1 or $\Delta c \operatorname{clp} B$ mutant strain ${ }^{\mathrm{a}}$

\begin{tabular}{|c|c|c|c|c|}
\hline Strain & Shoot dry weight (g/plant) & Root dry weight (g/plant) & Total biomass (g/plant) & Nodule dry weight (g/plant) \\
\hline Uninoculated & $0.155 \pm 0.034$ & $0.327 \pm 0.058$ & $0.482 \pm 0.082$ & 0 \\
\hline LMS-1 & $0.768 \pm 0.136$ & $0.445 \pm 0.104$ & $1.213 \pm 0.235$ & $0.224 \pm 0.143$ \\
\hline LMS-1 $\Delta c l p B$ & $0.638 \pm 0.146$ & $0.382 \pm 0.048$ & $1.019 \pm 0.189$ & $0.126 \pm 0.023$ \\
\hline Strain & Number of nodules & Pink nodules & White nodules & Average weight per nodule (mg/nodule) \\
\hline Uninoculated & 0 & 0 & 0 & 0 \\
\hline LMS-1 & $84 \pm 26$ & $71 \pm 19$ & $13 \pm 8$ & $2.454 \pm 0.792$ \\
\hline LMS-1 $\Delta c l p B$ & $85 \pm 11$ & $52 \pm 9$ & $33 \pm 2^{b}$ & $1.520 \pm 0.387$ \\
\hline
\end{tabular}

${ }^{a}$ Results obtained from a plant growth assay using chickpea plants inoculated with Mesorhizobium ciceri LMS-1 and $M$. ciceri LMS-1 $\Delta$ clpB strains under controlled conditions in a growth chamber. No nodules were obtained in uninoculated plants. Data correspond to the mean \pm standard deviation values from four plants for each treatment after eight weeks of inoculation.

${ }^{\mathrm{b}}$ Statistical significant differences $(P<0.05)$. 
higher proportion of undifferentiated bacteria, namely immature bacteroids (Fig. 6C). However, no significant differences between the invasion threads and release pockets were observed between the nodules formed by either strain (Fig. 6D and E). Moreover, in the fixation zone found in some nodules induced by the $\Delta c l p B$ mutant strain, the bacteroid organization within the cortical cells was well defined and similar to the wild-type strain (Fig. 6F).

Initial interaction of the $\Delta c l p B$ mutant with chickpea roots.

In order to determine if the delay in nodule appearance observed in plants inoculated with the $\Delta c \operatorname{lp} B$ mutant strain in the hydroponic assay could be due to a failure in the first stages of the mutant strain's interaction with the plant roots, the infection processes of the $\Delta c \operatorname{lp} B$ mutant and wild-type strains were compared. To visualize rhizobia attachment to root hairs and their ability to grow on the root surface and form infection threads in root hairs, the $M$. ciceri LMS-1 and M. ciceri LMS-1 $\triangle c l p B$ strains, harboring plasmid pMRGFP containing the constitutively expressed green fluorescent protein gene $(g f p)$, were used. Four days after chickpea root inoculation with either $\triangle c l p B$ mutant or wild-type strain, the roots and root hairs were visualized, using confocal spectral microscopy.

Root-hair attachment of rhizobia and their ability to grow on the root surface and form infection threads in root hairs were compared. At 4 days after chickpea root inoculation, attachment

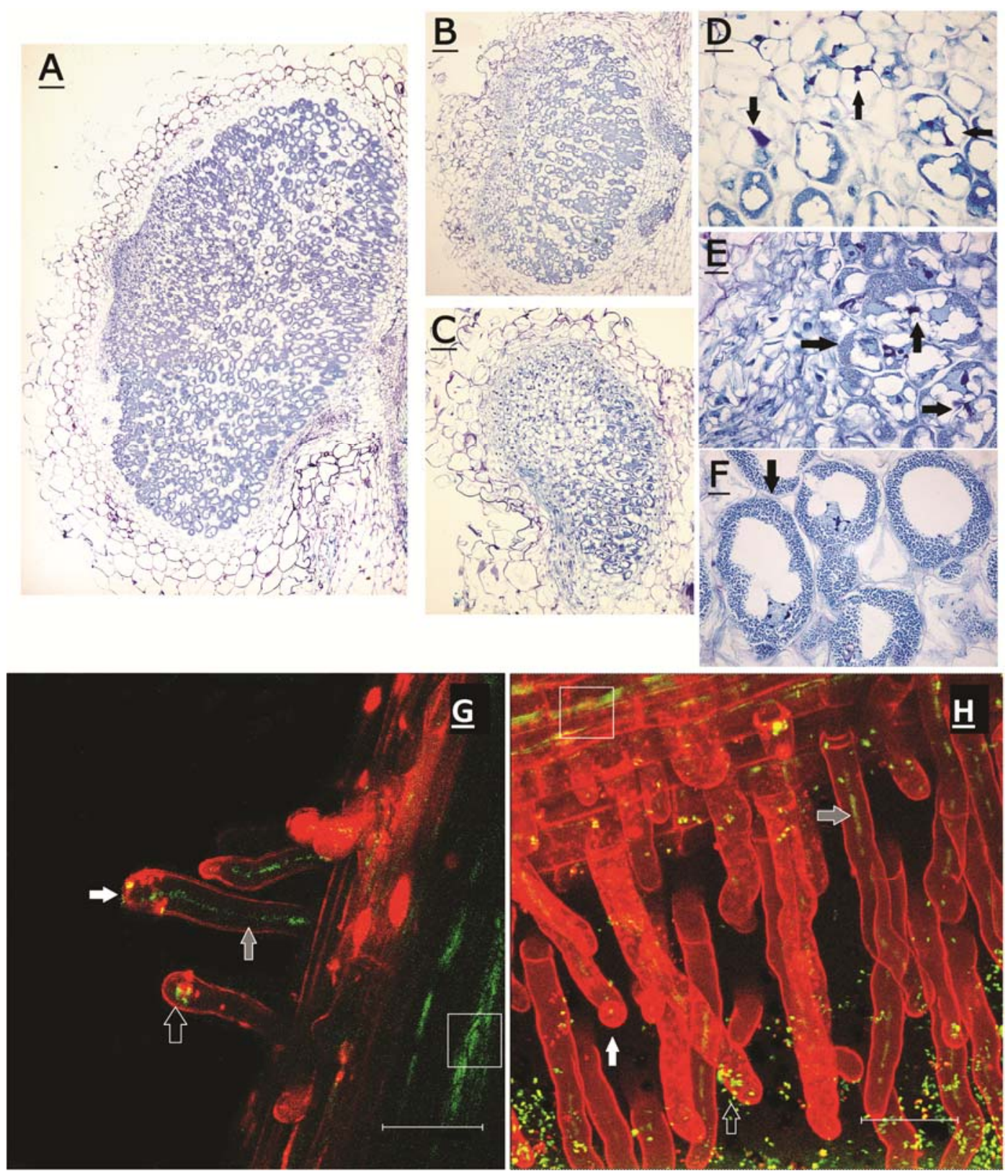

Fig. 6. Bright field micrographs of $2-\mu \mathrm{m}$ histological sections of representative embedded pink nodules stained with toluidine blue formed by A, the wildtype Mesorhizobium ciceri LMS-1 or $\mathbf{B}$ to $\mathbf{F}$, the $\Delta c l p B$ mutant strains. A to $\mathbf{C}$, Sections of entire nodules; $\mathbf{D}$, higher magnification of $\Delta c l p B$ mutant nodules invasion zone, $\mathbf{E}$, interzone, and $\mathbf{F}$, fixation zone. Black arrows in D show pockets of intercellular bacteria and infection threads emerging from them; black arrows in E show infected cortical cell and bacteria released from the infection threads into the root cortical cells; the black arrow in F shows the bacteroid differentiation and indicates the complete symbiosome organization. Magnification in A to C, 50×; D to F, 630×. Confocal laser scanning micrographs of propidium iodide-stained roots inoculated with green fluorescent protein-tagged LMS-1 and $\Delta c l p B$ mutant strains showing the initial infection process in chickpea roots. Images from chickpea root and root hairs were obtained 4 days after inoculation with either $\mathbf{G}$, wild-type or $\mathbf{H}, \Delta c l p B$ mutant strains. Roothair curling formed by either strain (closed white arrows); infection threads on root hairs (closed gray arrows); caps on root hairs tips (open white arrows), rhizobial attachment on roots (square). $\mathrm{G}$ and $\mathrm{H}$ scale bars correspond to 30 and $40 \mu \mathrm{m}$, respectively. 
of numerous cells to roots and root hairs was visible with both strains (Fig. 6G and H). Bacteria were located mainly on roots but were also found on root-hair tips and forming caps. Curled root hair, infection thread initiation, and extension to root epidermal cells inside of some of the root hairs were also observed with both strains. Overall, no differences in the infection abilities of wild-type and $\Delta c l p B$ mutant cells were detected.

\section{DISCUSSION}

In the present work, a ClpB chaperone knockout mutant from the strain $M$. ciceri LMS-1 was obtained. Our results indicate that $\operatorname{clpB}$ is a single copy gene in the $M$. ciceri LMS- 1 genome. Similarly, the completely sequenced genomes of Mesorhizobium strains, namely Mesorhizobium sp. strain MAFF303099 (Kaneko et al. 2000), M. opportunistum WSM2075 ${ }^{\mathrm{T}}$ (NC_ 015675), M. australicum WSM2073 ${ }^{\mathrm{T}}$ (National Center for Biotechnology Information, Mesorhizobium australicum WSM2073 webpage), and M. ciceri bv. biserrulae WSM1271 (NC_014923) show a single copy $\operatorname{clp} B$ gene. Furthermore, the $\operatorname{clp} B$ sequences from the different Mesorhizobium strains show a high similarity.

The $\Delta \operatorname{clp} B$ mutant strain tolerance to environmental stress conditions as well as its involvement in the symbiotic process with chickpea plants were evaluated. The evaluation of the ClpB mutant phenotype under abiotic stresses showed that it was unable to grow after a heat shock, and it was more sensitive to acid shock than the wild-type strain. Our results confirm that ClpB is essential in heat-shock tolerance in $M$. ciceri LMS-1. This is in agreement with the transcriptomic study conducted by Sauviac and associates (2007), which showed $c l p B$ gene upregulation by heat shock in Ensifer meliloti cells. Similar results were observed in diverse bacteria such as E. coli (Squires et al. 1991; Zolkiewski 1999), Vibrio cholera (Nag et al. 2005), Synechococcus spp. (Eriksson and Clarke 2000), and Brucella suis (Ekaza et al. 2001). In contrast, no difference between growth of wild-type and $\Delta c l p B$ mutant strains under cold temperatures was found. Similar results were obtained previously in Listeria monocytogenes (Chastanet et al. 2004) and E. coli (Strocchi et al. 2006). Strocchi and associates (2006) suggested that low temperatures may lead to inactivation of a few key cold-sensitive chaperoneinteracting proteins, such as $\mathrm{ClpB}$, DnaK, and GroEL, in E. coli. It is possible that the absence of differences in cold tolerance between wild-type and $\Delta c l p B$ mutant strains may be due to the cold inactivation of these chaperones, namely $\mathrm{ClpB}$, in the wildtype strain.

Under acid or salt continuous-stress conditions, no difference between the growth curves of the wild-type and $\Delta c l p B$ mutant strains was observed. Similar results were obtained when cells were subjected to an acid or salt shock. In contrast, when the cells were subjected to an acid shock followed by growth under continuous mild acid conditions, the $\Delta \operatorname{clp} B$ mutant displayed a higher sensitivity as compared with the wild-type strain, indicating the involvement of $\mathrm{ClpB}$ in acid response. This result corroborates previous studies (de Lucena et al. 2010) suggesting that $\mathrm{ClpB}$ is involved in acid-response in Ensifer meliloti cells. Moreover, Reid and associates (2008) identified several genes, including $\operatorname{clp} B$, which may be involved in acid tolerance of Campylobacter jejuni.

Interestingly, the $\Delta c l p B$ mutant showed a higher ability to overcome salt stress following a salt shock, compared with the wild-type strain. This may result from the induction of genes upon salt shock that were useful afterwards to overcome salt stress to a higher extent in the mutant than in the wild-type strain. Nevertheless, further studies are required to clarify this unexpected result.

Our results indicate that $\mathrm{ClpB}$ is essential for heat-shock response and is involved in acid tolerance, suggesting that both stress responses involve the action of this chaperone. Interestingly, Reid and associates (2008), using transcriptomic analysis in Campylobacter jejuni in vivo and in vitro conditions, suggested a common response to acid stress and heat shock involving the upregulation of most heat-shock genes, namely clpB, dnaK, groEL, and groES.

In the present study, the role of the chaperone $\mathrm{ClpB}$ in the chickpea-Mesorhizobium symbiosis was also examined. Although the shoot and root dry weights of chickpea plants inoculated with the $\Delta c l p B$ mutant strain were lower compared with the ones obtained with the wild-type strain, these differences were not statistically significant, suggesting that $\mathrm{ClpB}$ is not essential for the successful symbiotic nitrogen-fixation. This is supported by previous studies in Ensifer meliloti cells showing that a mutation in $r p o H 1$, which regulates the $\mathrm{ClpB}$ expression (de Lucena et al. 2010), does not affect the expression of the major nitrogen-fixation genes (Mitsui et al. 2004).

Although the plant development obtained with the $\Delta c \operatorname{lp} B$ mutant and wild-type strain was statistically similar, the nodules induced by the mutant strain showed a slower development. The nodulation kinetics showed a 6- to 8-day delay in nodule appearance in chickpea plants inoculated with the $\triangle c l p B$ mutant strain when compared with the wild-type strain. Furthermore, a higher proportion of the nodules formed by the mutant strain were small and white. This result was corroborated by the analysis of the histological sections of nodules formed by the $\Delta \operatorname{clp} B$ mutant strain, showing that most of the nodules presented a low number of bacteroids. The delay observed in nodule appearance and development probably contributes to the lower number of effective nodules of chickpea plants obtained with the $\Delta c l p B$ mutant strain. Altogether, our results suggest that $\mathrm{ClpB}$ is not essential for the establishment of a successful symbiosis with chickpea plants but is involved in the process of nodule formation and development.

In addition, our results indicate that nodC gene expression is lower in the $\Delta c l p B$ mutant, suggesting that $\mathrm{ClpB}$ is involved in the molecular signaling between both partners. A previous study of Ogawa and Long (1995) showed that the Ensifer meliloti GroEL chaperone is required for regulation of early nod genes by the transcription activator NodD. This protein is required for the induction of nodC expression, as shown in Ensifer meliloti (Mulligan and Long 1985) and in Rhizobium leguminosarum (Rossen et al. 1985). The lower levels of nodC transcript detected in the mutant strain, particularly under the stress condition, suggest that the delay in nodule formation by the $\Delta \operatorname{clp} B$ mutant could be related to its inability to activate properly the expression of the nod genes due to an inappropriate folding of the NodD protein.

Oke and Long (1999) suggested that, among the genes needed for bacteroid formation, some are specific for symbiosis and others are involved in the physiological adaptation to the environmental conditions within and outside the nodule. More recently, transcriptomic and proteomic analyses of nodules or bacteroids suggested that chaperone genes, including $\mathrm{ClpB}$, are involved in the symbiosis process (Djordjevic 2004; Karunakaran et al. 2009; Sarma and Emerich 2005). Shimoda and associates (2008) suggested the interaction between chaperones during symbiosis, namely $\mathrm{ClpB}$ with $\mathrm{ClpA}$, as part of a protease complex that functions in protein processing during symbiosis. Nomura and associates (2010) verified, by analysis of differential protein profiles of Bradyrhizobium japonicum bacteroids, that a number of chaperone proteins were overexpressed at the onset of the nitrogen fixation. Several studies on the symbiotic performance of strains mutated in genes of other chaperones suggested their involvement in the symbiosis. For example, Nogales and associates (2002) found that a dnaJ mutant of Rhi- 
zobium tropici was able to form nodules in Phaseolus vulgaris; however, this mutant showed low nitrogenase activity. The DnaK chaperone seems to be required for optimum symbiotic function in Ensifer meliloti (Summers et al. 1998). A double mutation on groEL3 and groEL4 genes affects the symbiotic performance in B. japonicum (Fischer et al. 1999).

It is acceptable that the symbiotic process is affected by the ability of rhizobial cells to respond to environmental stresses encountered when infecting or within the plant host. Marschner (2006) reported that the environmental $\mathrm{pH}$ in the rhizosphere of the leguminous host plant is decreased due to the protons and organic acids excreted by the plants. Moreover, rhizobia have to face acid conditions within the plant cell, due to the transport of protons or ionized acids that acidify the symbiosomes. In addition, rhizobia have to deal with the low oxygen concentration in the nodules, leading to the production of organic acids that inhibit the regulation of the cytoplasmic pH (Perez-Galdona and Kahn 1994).

Furthermore, several studies in rhizobia showed the induction of genes encoding molecular chaperones and proteases such as ClpB under acidity or microaerobic conditions in rhizobia, supporting their involvement in the protection of proteins from denaturation and aggregation (de Lucena et al. 2010; Puskás et al. 2004; Uchiumi et al. 2004).

Taking into account all these studies, it is probable that the involvement of $\mathrm{ClpB}$ in symbiosis is by disaggregating protein aggregates formed in bacteria subjected to atypical conditions, such as $\mathrm{pH}$ shifts or microaerobiosis, within the plant cells and nodules. The lower nod-gene expression by the $\Delta c l p B$ mutant strain compared with the wild-type strain plus the stress effects on $\Delta \operatorname{clpB}$ mutant growth suggest that the delay in nodule formation and development may be due to a lower ability to counteract the stress conditions within the host plant and nodule and to activate properly the expression of the nod genes. The lack of $\mathrm{ClpB}$, particularly in atypical conditions within the root cells, may result in some aggregation of the NodD proteins that fail to induce the normal expression of the $\operatorname{nod} A, \operatorname{nodB}$, and $\operatorname{nod} C$ genes, thus leading to the delay in nodulation observed with the mutant strain.

Assuming that the $\mathrm{ClpB}$ function is protein disaggregation, we can speculate that nodule formation and development involve changes in physiological conditions that lead to protein aggregation, thus requiring the $\mathrm{ClpB}$ action. However, further studies are required to clarify the role of this major chaperone in rhizobia during symbiosis.

Our results indicate that, in Mesorhizobium ciceri, $\mathrm{ClpB}$ is involved in the response to several stresses, namely heat and acid shocks. Furthermore, the $\mathrm{ClpB}$ absence caused a delay in the nodule formation and development, in spite of the ability of the $\Delta \operatorname{clp} B$ mutant strain to establish a symbiotic relationship with chickpea plants. Overall, in Mesorhizobium ciceri LMS1 , the chaperone ClpB seems to play an important role in overcoming stress conditions as free-living cells as well as in the symbiosis process. To our knowledge, this is the first report supporting the involvement of chaperone $\mathrm{ClpB}$ from rhizobia in the symbiotic nodulation process.

\section{MATERIALS AND METHODS}

\section{Plasmids, bacterial strains and growth conditions.}

Bacterial strains and plasmids used are described in Table 1. Mesorhizobium ciceri LMS-1 and its derivatives LMS- $1 \Delta c l p B$ and complemented strains were grown in tryptone yeast (TY) or yeast extract mannitol (YEM) broth at $28^{\circ} \mathrm{C}$ for routine use and were preserved in $30 \%$ (vol $/ \mathrm{vol}$ ) glycerol at $-80^{\circ} \mathrm{C}$. The $E$. coli strains were grown at $37^{\circ} \mathrm{C}$ in Luria Bertani broth supplemented with appropriate antibiotics. The final concentrations of antibiotics were kanamycin at $50 \mu \mathrm{g} \mathrm{ml}^{-1}$, ampicillin at 100 $\mu \mathrm{g} \mathrm{ml} l^{-1}$, and chloramphenicol at $25 \mu \mathrm{g} \mathrm{ml}^{-1}$.

\section{DNA methods and construction of LMS-1 derivative strains.}

Total DNA from rhizobial strains was extracted, using the E.Z.N.A. bacterial DNA kit (Omega Bio-Tek, Norcross, GA, U.S.A.) according to the manufacturer's suggested protocol. Plasmid DNA was obtained by using the DNA-Spin plasmid DNA purification kit (Intron, Kyunggi-do, Korea) following the manufacturer's instructions. Unless specified otherwise, molecular techniques were performed using standard protocols (Sambrook and Russell 2001).

The $M$. ciceri LMS-1 $c l p B$ gene $(2,607 \mathrm{nt})$ was isolated by PCR amplification. First, an internal fragment of 1,388 bp was obtained, using heterologous primers (Brígido et al. 2012) based on the $\operatorname{clpB}$ sequence from Mesorhizobium sp. strain MAFF303099. The stop region sequence was obtained by inverse PCR. The complete gene sequence was obtained by PCR amplification using a forward primer based on the gene sequence of Mesorhizobium sp. strain MAFF303099. To generate the $\Delta \operatorname{lp} B$ deletion mutant strain, a $\operatorname{clp} B$ gene fragment of 2,558 bp was amplified using the primers clpB-F1 (5'-TGAGA AGTACTCCGAGCGCGT-3') and clpB-R1 (5'-GGAAGTTCA GCCGGTCGGAA- $3^{\prime}$ ). The PCR product was purified using the Gel Band purification kit (GE Healthcare, Buckinghamshire, U.K.) according to the manufacturer's instructions. The $\operatorname{clp} B$ gene fragment was cloned using pGEM-T Easy vector system (Promega, Madison, WI, U.S.A.) following the manufacturer's instructions. An internal 675-bp Eco47III-BamHI fragment from the cloned $c l p B$ gene fragment was removed. The truncated $\operatorname{clp} B$ gene was cloned as an EcoRI fragment into plasmid pK18mobsacB and was transferred to the Mesorhizobium ciceri LMS-1 by triparental mating, using pRK2013 as a helper. Double recombinants were selected as previously described (Schafer et al. 1994).

To complement the disruption of the $\operatorname{clp} B$ gene, replacement of the disrupted $\operatorname{clp} B$ gene by the complete $\operatorname{clp} B$ gene in its original genomic location was performed. The complete $\operatorname{clp} B$ gene $(2,607 \mathrm{bp})$ was amplified using the primers clpB-XbaI-F (5'-CTAGAGATGAACCTTGAGAAGTAC-3') and clpBXbaI-R (5'-CTAGACAGGATCAGGCTGCCGCTT-3') and was cloned, using pGEM-T Easy vector system (Promega), and introduced as an $\mathrm{XbaI}$ fragment into plasmid pK18mobsacB. Complemented strain was generated by replacement of the $\operatorname{clp} B$ gene disrupted for the complete one by following the same approach to obtain the $\Delta c l p B$ mutant strain, as mentioned above.

To confirm the successful allele replacement in $M$. ciceri LMS-1 derivatives, PCR analysis and Southern hybridization were conducted. PCR analysis was performed as previously described (Brígido et al. 2012). Briefly, for Southern hybridization, about $2 \mu \mathrm{g}$ of total DNA from Mesorhizobium ciceri LMS-1 and its derivatives were digested with the restriction enzyme HindIII. A 1,388-bp fragment of the $\operatorname{clpB}$ gene of $M$. ciceri LMS-1 was amplified as described previously (Brígido et al. 2012) and was used as a DNA probe, which was labeled using the DIG high prime DNA labeling and detection starter kit II (Roche Applied Science, Basel, Switzerland) according to the manufacture's protocol. The hybridization process was carried out using Dig Easy Hyb hybridization buffer (Roche Applied Science) at $42^{\circ} \mathrm{C}$, followed by stringency washes at room temperature and at $68^{\circ} \mathrm{C}$. The immunological detection was performed according to the manufacturer's instructions.

Mesorhizobium ciceri LMS-1 and $\Delta c l p B$ deletion mutant strains were transformed with the $g f p$ gene. For that, the plasmid pMRGFP (Garcia-Fraile et al. 2012), containing the con- 
stitutively expressed $g f p$ gene, was used to transform both mesorhizobia strains by triparental conjugation, as previously described (Nascimento et al. 2012).

\section{Analysis of stress tolerance.}

To evaluate the stress tolerance of the Mesorhizobium ciceri LMS-1 $\Delta c l p B$ strain and compared it with the wild-type strain, bacterial growth was evaluated by measuring optical density at $540 \mathrm{~nm}\left(\mathrm{OD}_{540}\right)$ every $6 \mathrm{~h}$ during $54 \mathrm{~h}$ of growth in liquid medium. Mesorhizobium ciceri LMS-1 and its derivatives were grown in YEM medium at $28^{\circ} \mathrm{C}$ overnight until late log phase $(16$ to $18 \mathrm{~h})$. After inocula growth, the $\mathrm{OD}_{540}$ was adjusted at 0.03 and was submitted to different stress conditions. Three replicas per treatment were done.

For continuous cold and heat stress, mesorhizobia cells were grown at 15 or $37^{\circ} \mathrm{C}$, respectively for 54 h. For heat shock, cells were incubated at $45^{\circ} \mathrm{C}$ for $1 \mathrm{~h}, 48^{\circ} \mathrm{C}$ for $15 \mathrm{~min}$ or $50^{\circ} \mathrm{C}$ for 5 min, and were then grown at $28^{\circ} \mathrm{C}$ for $54 \mathrm{~h}$. For cold shock, cells were subjected to $4^{\circ} \mathrm{C}$ for $1 \mathrm{~h}$, followed by $28^{\circ} \mathrm{C}$ for $54 \mathrm{~h}$. Growth at $28^{\circ} \mathrm{C}$ for $54 \mathrm{~h}$ was considered the control condition.

To study the effect of acid stress, mesorhizobia strains were grown in YEM medium buffered with $25 \mathrm{mM}$ homopiperazine-N,N'-bis-2-(ethanesulfonic acid) (HOMOPIPES) for $\mathrm{pH}$ 5. For control conditions, YEM was buffered with $20 \mathrm{mM} 2$ morpholinoethanesulfonic acid (MES) at $\mathrm{pH}$ 7. To evaluate the effect of an acidic upshift, the cells were subjected for $1 \mathrm{~h}$ in YEM (pH 3) and were then grown in YEM (pH 7) and YEM $(\mathrm{pH} 5)$ at $28^{\circ} \mathrm{C}$ for $54 \mathrm{~h}$.

For salt stress, mesorhizobia cells were grown in YEM supplemented with $1.5 \% \mathrm{NaCl}$ at $28^{\circ} \mathrm{C}$ for $54 \mathrm{~h}$. For control conditions, YEM with no extra addition of $\mathrm{NaCl}$ was used. Bacterial cells were also submitted to a salt shock in YEM supplemented with $5 \% \mathrm{NaCl}$ at $28^{\circ} \mathrm{C}$ for $1 \mathrm{~h}$ and were then grown in YEM or in YEM supplemented with $1.5 \% \mathrm{NaCl}$ for $54 \mathrm{~h}$ at $28^{\circ} \mathrm{C}$.

\section{Immunoblotting.}

ClpB was detected in cells by immunoblotting using a rabbit polyclonal antibody against $E$. coli $\mathrm{ClpB}$ (supplied by $\mathrm{M}$. Zolkiewski, Kansas State University, Manhattan, KS, U.S.A.). After growth under control and heat-shock conditions, cells were harvested by centrifugation at $16,000 \times g$ for $3 \mathrm{~min}$, were washed in TE buffer (10 mM Tris, $1 \mathrm{mM}$ EDTA, $\mathrm{pH}$ 8.0), and were resuspended in $500 \mu \mathrm{l}$ of sterile water. Cells were kept on ice during sonication and were then centrifuged at $13,500 \times g$ for $12 \mathrm{~min}$ at $4^{\circ} \mathrm{C}$ and were resuspended in $500 \mu \mathrm{l}$ of sterile water. Protein extracts containing similar concentration $( \pm 15 \mu \mathrm{g})$ were then separated on a $12 \%$ linear polyacrylamide gel and were electrophoretically transferred to a nitrocellulose membrane (Bio-Rad, Hercules, CA, U.S.A.) according to the manufacturer's instructions. Following transfer, the membrane was blocked with $1 \%$ (wt/vol) low-fat milk in Tris-buffered saline (TBS) buffer for $1 \mathrm{~h}$ and was incubated overnight with rabbit polyclonal antibodies against $E$. coli $\mathrm{ClpB}$ protein diluted 1:500. The membrane was washed three times with TBSTween $(0.05 \%$ Tween 20$)$ and was incubated for $1 \mathrm{~h}$ with 1:500 dilution of anti-rabbit immunoglobulin G-peroxidase antibody (Sigma-Aldrich, St. Louis). The membrane was washed with TBS and was visualized with peroxidase substrates (4chloro-1-naphthol, Sigma-Aldrich) in a color development buffer.

\section{Analysis of the symbiotic phenotype.}

In order to evaluate the symbiotic performance of the $\Delta \operatorname{clp} B$ and wild-type mesorhizobia strains in chickpea plants, a plantgrowth assay was conducted in a growth chamber. Chickpea seeds (cultivar Chk 3226) were surface-sterilized and pregerminated as described previously (Nascimento et al. 2012). Af- ter germination, the seeds were transferred to plastic pots filled with sterile vermiculite and were grown in a growth chamber under a 16-h-light and 8-h-dark cycle and $24^{\circ} \mathrm{C}$-day and $18^{\circ} \mathrm{C}$ night temperature at a relative humidity of $65 \%$ for 8 weeks.

The rhizobia strains were grown in TY liquid medium at $28^{\circ} \mathrm{C}$ for $72 \mathrm{~h}$. After incubation, the cell suspension was centrifuged at $10.000 \times g$ and was resuspended in fresh TY liquid medium. Finally, the bacterial cultures were standardized to an $\mathrm{OD}_{540}$ of 1.0 , and $1 \mathrm{ml}$ of the bacterial suspension was used to inoculate each seed. Four replicates were used for each treatment. A nitrogen-free nutrient solution (Broughton and Dilworth 1971) was applied three times a week. Uninoculated plants were used as negative control. After 8 weeks, the plants were harvested and several parameters were measured, such as shoot dry weight, root dry weight, number of nodules, and nodule dry weight.

In order to evaluate the nodule kinetics and development, a hydroponic plant-growth assay was conducted using chickpea plants inoculated with either $M$. ciceri LMS-1 or $\Delta$ clpB mutant strain. The bacterial cultures were grown in TY for 72-h days. The bacterial suspension was centrifuged at $10,000 \times g$ and was resuspended in nitrogen-free nutrient solution (Harper and Gipson 1984) diluted in sterile water (1:4). The bacterial suspension was adjusted at an $\mathrm{OD}_{540}$ of 0.6. Finally, the pregerminated roots of the seeds were put into contact with the bacterial suspension overnight at $28^{\circ} \mathrm{C}$ in the dark. The chickpea seeds were washed in nutrient solution and were put in a container with 5 liters of nutrient solution in a growth chamber under controlled conditions. For negative controls, no bacterial culture was used. Five seeds per treatment were used. The nutrient solution was replaced every week, and the nodule formation and development were recorded every three days for 35 days. The nutrient solution was aerated using an aquarium pump.

\section{Analysis of nodC gene expression by semiquantitative RT-PCR.}

To evaluate the nod gene expression in the $\Delta c l p B$ strain, analysis of the nodC expression in the wild-type and mutant strains was performed by semiquantitative RT-PCR (Moscatiello et al. 2009). Induction of the nod genes was performed using chickpea root exudates, which were obtained as described by Srivastava and associates (1999). The root exudates were added to exponential-phase cells, and the cultures were incubated for $6 \mathrm{~h}$ at $28^{\circ} \mathrm{C}$. Cells were then submitted to control or heat-shock $\left(42^{\circ} \mathrm{C}\right.$ for $\left.30 \mathrm{~min}\right)$ conditions.

Total RNA was extracted using the RNeasy mini kit (Qiagen, Valencia, CA, U.S.A.) according to the manufacturer's protocol. After extraction, about $2 \mu \mathrm{g}$ of total RNA were treated with DNase I (Roche Applied Science). Conversion of total RNA to cDNA was conducted using the RevertAid first-strand cDNA synthesis kit (Fermentas, Vilnius, Lithuania) according to the manufacture's suggestions. Amplification of 16S rRNA and nodC genes was performed as previously described (Laranjo et al. 2004; Rivas et al. 2007). Densitometric analysis of ethidium bromide-stained agarose gels was performed using Kodak Digital Science 1D version 2.0.3 (Eastman Kodak Company, New Haven, CT, U.S.A.). The $16 \mathrm{~S}$ rRNA gene was used to normalize the relative nodC transcript abundance. Three independent biological replicas were used to assess the nodC transcript levels. The viability of the mutant strain subjected to the heat shock was previously confirmed.

\section{Statistical analysis.}

The data obtained from the chickpea plant-growth assay was characterized by analysis of variance (ANOVA), and means were compared by one-way ANOVA. Statistical analysis was carried out using SPSS V.17 software (SPSS Inc., Chicago). 


\section{Microscopy.}

For analysis of the infection performance of the rhizobia strains, 4-day-old germinated chickpea seeds were inoculated with GFP-tagged mesorhizobia strains, as previously described (Robledo et al. 2011). After 4 days of inoculation, root hairs were examined by confocal spectral microscopy with a Leica confocal microscope equipped with krypton-argon laser using a blue excitation filter (excitation maximum $488 \mathrm{~nm} ; 530 \mathrm{~nm}$ long-pass filter), allowing simultaneous visualization of GFP and propidium iodide fluorescence. Roots and root hairs were stained with $10 \mu \mathrm{M}$ propidium iodide (Sigma-Aldrich). Projections were made from adjusted individual channels in the image stacks using Leica software.

Roots and nodules were excised from 25-day-old chickpea plants and were processed for light microscopy. The internal morphological features of chickpea nodules were examined by microscopy after toluidine blue staining. Pink nodules were fixed in $4 \%$ formaldehyde in $50 \mathrm{mM}$ phosphate buffer $(\mathrm{pH} \mathrm{8})$, were dehydrated in an increasing ethanol series, and were embedded in paraffin. Toluidine blue-stained sections $(2 \mu \mathrm{m})$ of embedded nodules were examined by light microscopy.

\section{ACKNOWLEDGMENTS}

This work was funded by FEDER Funds through the Operational Programme for Competitiveness Factors-COMPETE and National Funds through Fundação para a Ciência e a Tecnologia (FCT)-Foundation for Science and Technology under the Strategic Project PEst-C/AGR/UI0115/ 2011 and has received funding from FCT (PTDC/BIO/80932/2006) and co-financed by the EU-FEDER (European Union Fundo Europeu de Desenvolvimento Regional) (FCOMP-01-0124-FEDER-007091) and the Spanish Ministry of Science \& Innovation (MICINN) (AGL2008-03360). C. Brígido acknowledges a Ph.D. fellowship (SFRH/BD/30680/2006) from FCT and financial support from ICAAM (Instituto de Ciências Agrárias e Ambientais Mediterrânicas). E. Menendez acknowledges a Ph.D. fellowship (BES-2009-022401)from the Formación del Personal Investigador (FPI)-MICINN, and M. Robledo acknowledges a Ph.D. fellowship from the MICINN (Spain). The authors thank G. Mariano for technical assistance and M. Zolkiewski, Kansas State University, U.S.A. for his kindness in providing the antibody against $E$. coli $\mathrm{ClpB}$.

\section{LITERATURE CITED}

Barnett, M. E., Zolkiewska, A., and Zolkiewski, M. 2000. Structure and activity of ClpB from Escherichia coli-Role of the amino- and carboxyl-terminal domains. J Biol Chem 275:37565-37571.

Barnett, M. E., Nagy, M., Kedzierska, S., and Zolkiewski, M. 2005. The amino-terminal domain of $\mathrm{ClpB}$ supports binding to strongly aggregated proteins. J. Biol. Chem. 280:34940-34945.

Brígido, C., Alexandre, A., and Oliveira, S. 2012. Transcriptional analysis of major chaperone genes in salt-tolerant and salt-sensitive mesorhizobia. Microbiol. Res. doi:10.1016/j.micres.2012.01.006. Published online.

Broughton, W. J., and Dilworth, M. J. 1971. Control of leghaemoglobin synthesis in snake beans. Biochem. J. 125:1075-1080.

Chastanet, A., Derre, I., Nair, S., and Msadek, T. 2004. clpB, a novel member of the Listeria monocytogenes CtsR regulon, is involved in virulence but not in general stress tolerance. J. Bacteriol. 186:1165-1174.

de Lucena, D. K., Pühler, A., and Weidner, S. 2010. The role of sigma factor $\mathrm{RpoH} 1$ in the $\mathrm{pH}$ stress response of Sinorhizobium meliloti. BMC Microbiol. 10:17. Published online.

DeSantis, M. E., and Shorter, J. 2012. The elusive middle domain of Hsp104 and ClpB: Location and function. Biochem. Biophys. ActaMole Cell Res 1823:29-39.

Ditta, G., Stanfield, S., Corbin, D., and Helinski, D. R. 1980. Broad-host range DNA cloning system for Gram-negative bacteria: Construction of a gene bank of Rhizobium meliloti. Proc. Natl. Acad. Sci. U.S.A.-Biol. 77:7347-7351.

Djordjevic, M. A. 2004. Sinorhizobium meliloti metabolism in the root nodule: A proteomic perspective. Proteomics 4:1859-1872.

Djordjevic, M. A., Chen, H. C., Natera, S., van Noorden, G., Menzel, C., Taylor, S., Renard, C., Geiger, O., and Weiller, G. F. 2003. A global analysis of protein expression profiles in Sinorhizobium meliloti: Discovery of new genes for nodule occupancy and stress adaptation. Mol. Plant-Microbe Interact. 16:508-524.
Dougan, D. A., Mogk, A., Zeth, K., Turgay, K., and Bukau, B. 2002. AAA plus proteins and substrate recognition, it all depends on their partner in crime. FEBS (Fed. Eur. Biochem. Soc.) Lett. 529:6-10.

Doyle, S. M., and Wickner, S. 2009. Hsp104 and ClpB: Protein disaggregating machines. Trends Biochem. Sci. 34:40-48.

Ekaza, E., Teyssier, J., Ouahrani-Bettache, S., Liautard, J. P., and Kohler, S. 2001. Characterization of Brucella suis clpB and clpAB mutants and participation of the genes in stress responses. J. Bacteriol. 183:26772681.

Eriksson, M. J., and Clarke, A. K. 2000. The Escherichia coli heat shock protein $\mathrm{CIpB}$ restores acquired thermotolerance to a cyanobacterial clpB deletion mutant. Cell Stress Chaperones 5:255-264.

Finan, T. M., Kunkel, B., Devos, G. F., and Signer, E. R. 1986. Second symbiotic megaplasmid in Rhizobium meliloti carrying exopolysaccharide and thiamine synthesis genes. J. Bacteriol. 167:66-72.

Fischer, H. M. 1994. Genetic regulation of nitrogen fixation in rhizobia. Microbiol. Rev. 58:352-386.

Fischer, H. M., Schneider, K., Babst, M., and Hennecke, H. 1999. GroEL chaperonins are required for the formation of a functional nitrogenase in Bradyrhizobium japonicum. Arch. Microbiol. 171:279-289.

Gage, D. J. 2004. Infection and invasion of roots by symbiotic, nitrogenfixing rhizobia during nodulation of temperate legumes. Microbiol. Mol. Biol. Rev. 68:280-300.

Garcia-Fraile, P., Carro, L., Robledo, M., Ramirez-Bahena, M.-H., FloresFelix, J.-D., Teresa, F. M., Mateos, P. F., Rivas, R., Mariano, I. J., Martinez-Molina, E., Peix, A., and Velazquez, E. 2012. Rhizobium promotes non-legumes growth and quality in several production steps: Towards a biofertilization of edible raw vegetables healthy for humans. Plos One 7. Published online.

Goloubinoff, P., Mogk, A., Ben Zvi, A. P., Tomoyasu, T., and Bukau, B. 1999. Sequential mechanism of solubilization and refolding of stable protein aggregates by a bichaperone network. Proc. Natl. Acad. Sci. U.S.A. 96:13732-13737.

Harper, J. E., and Gipson, A. H. 1984. Differential nodulation tolerance to nitrate among legume species. Crop Sci. 24:797-801

Hartl, F. U. 1996. Molecular chaperones in cellular protein folding. Nature 381:571-579.

Hartl, F. U., Bracher, A., and Hayer-Hartl, M. 2011. Molecular chaperones in protein folding and proteostasis. Nature 475:324-332.

Hungria, M., and Stacey, G. 1997. Molecular signals exchanged between host plants and rhizobia: Basic aspects and potential application in agriculture. Soil Biol. Biochem. 29:819-830.

Hungria, M., and Vargas, M. A. T. 2000. Environmental factors affecting $\mathrm{N}_{2}$ fixation in grain legumes in the tropics, with an emphasis on Brazil. Field Crops Res. 65:151-164.

Kaneko, T., Nakamura, Y., Sato, S., Asamizu, E., Kato, T., Sasamoto, S., Watanabe, A., Idesawa, K., Ishikawa, A., Kawashima, K., Kimura, T., Kishida, Y., Kiyokawa, C., Kohara, M., Matsumoto, M., Matsuno, A., Mochizuki, Y., Nakayama, S., Nakazaki, N., Shimpo, S., Sugimoto, M., Takeuchi, C., Yamada, M., and Tabata, S. 2000. Complete genome structure of the nitrogen-fixing symbiotic bacterium Mesorhizobium loti. DNA Res. 7:331-338.

Karunakaran, R., Ramachandran, V. K., Seaman, J. C., East, A. K., Mouhsine, B., Mauchline, T. H., Prell, J., Skeffington, A., and Poole, P. S. 2009. Transcriptomic analysis of Rhizobium leguminosarum biovar viciae in symbiosis with host plants Pisum sativum and Vicia cracca. J. Bacteriol. 191:4002-4014.

Kedzierska, S., Akoev, V., Barnett, M. E., and Zolkiewski, M. 2003. Structure and function of the middle domain of ClpB from Escherichia coli. Biochem. 42:14242-14248.

Laranjo, M., Machado, J., Young, J. P. W., and Oliveira, S. 2004. High diversity of chickpea Mesorhizobium species isolated in a Portuguese agricultural region. FEMS (Fed. Eur. Microbiol. Soc.) Microbiol. Ecol. 48:101-107.

Lee, S., Sowa, M. E., Watanabe, Y. H., Sigler, P. B., Chiu, W., Yoshida, M., and Tsai, F. T. F. 2003. The structure of clpB: A molecular chaperone that rescues proteins from an aggregated state. Cell 115:229-240.

Lee, U., Wie, C., Escobar, M., Williams, B., Hong, S. W., and Vierling, E. 2005. Genetic analysis reveals domain interactions of Arabidopsis Hsp100/ClpB and cooperation with the small heat shock protein chaperone system. Plant Cell 17:559-571.

Marschner, H. 2006. Mineral nutrition of higher plants. Academic Press, London.

Maurizi, M. R., and Xia, D. 2004. Protein binding and disruption by CIp/Hsp100 chaperones. Structure 12:175-183.

Mitsui, H., Sato, T., Sato, Y., Ito, N., and Minamisawa, K. 2004. Sinorhizobium meliloti $\mathrm{RpoH} 1$ is required for effective nitrogen-fixing symbiosis with alfalfa. Mol. Genet. Genomics 271:416-425.

Mogk, A., Schlieker, C., Strub, C., Rist, W., Weibezahn, J., and Bukau B. 2003. Roles of individual domains and conserved motifs of the AAA 
plus chaperone $\mathrm{ClpB}$ in oligomerization, ATP hydrolysis, and chaperone activity. J. Biol. Chem. 278:17615-17624.

Mogk, A., Hasiberger, T., Tessarz, P., and Bukau, B. 2008. Common and specific mechanisms of AAA plus proteins involved in protein quality control. Biochem. Soc. Transactions 36:120-125.

Moscatiello, R., Alberghini, S., Squartini, A., Mariani, P., and Navazio, L. 2009. Evidence for calcium-mediated perception of plant symbiotic signals in aequorin-expressing Mesorhizobium loti. BMC Microbiol 9. Published online.

Motohashi, K., Watanabe, Y., Yohda, M., and Yoshida, M. 1999. Heat-inactivated proteins are rescued by the DnaK center dot J-GrpE set and ClpB chaperones. Proc. Natl. Acad. Sci. U.S.A. 96:7184-7189.

Mulligan, J. T., and Long, S. R. 1985. Induction of Rhizobium meliloti nodC expression by plant exudates requires NodD. Proc. Nat. Acad. Sci. U.S.A. 82:6609-6613.

Nag, S., Das, S., and Chaudhuri, K. 2005. In vivo induced clpB1 gene of Vibrio cholerae is involved in different stress responses and affects in vivo cholera toxin production. Biochem. Biophys. Res. Commun. 331:1365-1373.

Nascimento, F., Brígido, C., Alho, L., Glick, B. R., and Oliveira, S. 2012. Enhanced chickpea growth promotion ability of a Mesorhizobium strain expressing an exogenous ACC deaminase gene. Plant Soil 353:221-230.

Neuwald, A. F., Aravind, L., Spouge, J. L., and Koonin, E. V. 1999. AAA(+): A class of chaperone-like ATPases associated with the assembly, operation, and disassembly of protein complexes. Genome Res. 9:27-43

Nogales, J., Campos, R., BenAbdelkhalek, H., Olivares, J., Lluch, C., and Sanjuan, J. 2002. Rhizobium tropici genes involved in free-living salt tolerance are required for the establishment of efficient nitrogen-fixing symbiosis with Phaseolus vulgaris. Mol. Plant-Microbe Interact. 15:225232

Nomura, M., Arunothayanan, H., Dao, T. V., Le, H. T. P., Kaneko, T., Sato, S., Tabata, S., and Tajima, S. 2010. Differential protein profiles of Bradyrhizobium japonicum USDA110 bacteroid during soybean nodule development. Soil Sci. Plant Nutr. 56:579-590.

Ogawa, J., and Long, S. R. 1995. The Rhizobium meliloti groELc locus is required for regulation of early nod genes by the transcription activator nodD. Gene Dev. 9:714-729.

Oke, V., and Long, S. R. 1999. Bacteroid formation in the Rhizobium-legume symbiosis. Curr. Opin. Microbiol. 2:641-646.

Oldroyd, G. E. D., and Downie, J. M. 2008. Coordinating nodule morphogenesis with rhizobial infection in legumes. Ann. Rev. Plant Biol. p 519-546.

Ott, T., van Dongen, J. T., Gunther, C., Krusell, L., Desbrosses, G., Vigeolas, H., Bock, V., Czechowski, T., Geigenberger, P., and Udvardi, M. K. 2005. Symbiotic leghemoglobins are crucial for nitrogen fixation in legume root nodules but not for general plant growth and development. Curr. Biol. 15:531-535.

Parsell, D. A., Kowal, A. S., Singer, M. A., and Lindquist, S. 1994. Protein disaggregation mediated by heat-shock protein Hsp104. Nature 372:475-478

Perez-Galdona, R., and Kahn, M. L. 1994. Effects of organic acids and low $\mathrm{pH}$ on Rhizobium meliloti 104A14. Microbiol. 140:1231-1235.

Pessi, G., Ahrens, C. H., Rehrauer, H., Lindemann, A., Hauser, F., Fischer, H. M., and Hennecke, H. 2007. Genome-wide transcript analysis of Bradyrhizobium japonicum bacteroids in soybean root nodules. Mol. Plant-Microbe Interact. 20:1353-1363.

Puskás, L. G., Nagy, Z. B., Kelemen, J. Z., Ruberg, S., Bodogai, M., Becker, A., and Dusha, I. 2004. Wide-range transcriptional modulating effect of ntrR under microaerobiosis in Sinorhizobium meliloti. Mol. Genet. Genomics 272:275-289.

Reid, A. N., Pandey, R., Palyada, K., Naikare, H., and Stintzi, A. 2008 Identification of Campylobacter jejuni genes involved in the response to acidic $\mathrm{pH}$ and stomach transit. Appl. Environ. Microbiol. 74:1583-1597.

Rivas, R., Laranjo, M., Mateos, P. F., Oliveira, S., Martinez-Molina, E., and Velazquez, E. 2007. Strains of Mesorhizobium amorphae and Mesorhizobium tianshanense, carrying symbiotic genes of common chickpea endosymbiotic species, constitute a novel biovar (ciceri) capable of nodulating Cicer arietinum. Lett. Appl. Microbiol. 44:412-418.

Robledo, M., Jiménez-Zurdo, J. I., Soto, M. J., Velázquez, E., Dazzo, F., Martínez-Molina, E., and Mateos, P. F. 2011. Development of functional symbiotic white clover root hairs and nodules requires tightly regulated production of rhizobial cellulase CelC2. Mol. Plant-Microbe Interact. 24:798-807.

Rossen, L., Shearman, C. A., Johnston, A. W. B., and Downie, J. A. 1985. The nodD gene of Rhizobium leguminosarum is autoregulatory and in the presence of plant exudates induces the $\operatorname{nod} A, B, C$ genes. EMBO (Eur. Mol. Biol. Organ.) J 4:3369-3373.

Sambrook, J., and Russell, D. W. 2001. Molecular Cloning: A Laboratory
Manual. Cold Spring Harbor Laboratory, New York.

Sanchez, Y., and Lindquist, S. L. 1990. Hsp104 required for induced thermotolerance. Science 248:1112-1115.

Sarma, A. D, and Emerich, D. W. 2005. Global protein expression pattern of Bradyrhizobium japonicum bacteroids: A prelude to functional proteomics. Proteomics 5:4170-4184.

Sauer, R. T., Bolon, D. N., Burton, B. M., Burton, R. E., Flynn, J. M. Grant, R. A., Hersch, G. L., Joshi, S. A., Kenniston, J. A., Levchenko, I., Neher, S. B., Oakes, E. S. C., Siddiqui, S. M., Wah, D. A., and Baker, T. A. 2004. Sculpting the proteome with AAA+ proteases and disassembly machines. Cell 119:9-18.

Sauviac, L., Philippe, H., Phok, K., and Bruand C. 2007. An extracytoplasmic function sigma factor acts as a general stress response regulator in Sinorhizobium meliloti. J. Bacteriol. 189:4204-4216.

Schafer, A., Tauch, A., Jager, W., Kalinowski, J., Thierbach, G., and Puhler, A. 1994. Small mobilizible multi-purpose cloning vectors derived from the Escherichia coli plasmids pK18 and pK19-selection of defined deletions in the chromosome of Corynebacterium glutamicum. Gene 145:69-73

Schirmer, E. C., Homann, O. R., Kowal, A. S., and Lindquist, S. 2004. Dominant gain-of-function mutations in Hsp104p reveal crucial roles for the middle region. Mol. Biol. Cell 15:2061-2072

Shimoda, Y., Shinpo, S., Kohara, M., Nakamura, Y., Tabata, S., and Sato, S. 2008. A large scale analysis of protein-protein interactions in the nitrogen-fixing bacterium Mesorhizobium loti. DNA Res. 15:13-23.

Soto, M. J., Domínguez-Ferreras, A., Perez-Mendoza, D., Sanjuan, J., and Olivares, J. 2009. Mutualism versus pathogenesis: The give-and-take in plant-bacteria interactions. Cell Microbiol. 11:381-388.

Squires, C. L., Pedersen, S., Ross, B. M., and Squires, C. 1991. ClpB is the Escherichia coli heat-shock protein F84.1. J. Bacteriol. 173:42544262

Srivastava, P., Sharma, P. K., and Dogra, R. C. 1999. Inducers of nod genes of Rhizobium ciceri. Microbiol. Res. 154:49-55.

Strocchi, M., Ferrer, M., Timmis, K. N., and Golyshin, P. N. 2006. Low temperature-induced systems failure in Escherichia coli: Insights from rescue by cold-adapted chaperones. Proteomics 6:193-206.

Summers, M. L., Elkins, J. G., Elliott, B. A., and McDermott, T. R. 1998 Expression and regulation of phosphate stress inducible genes in Sinorhizobium meliloti. Mol. Plant-Microbe Interact. 11:1094-1101.

Tsukada, S., Aono, T., Akiba, N., Lee, K. B., Liu, C. T., Toyazaki, H., and Oyaizu, H. 2009. Comparative genome-wide transcriptional profiling of Azorhizobium caulinodans ORS571 grown under free-living and symbiotic conditions. Appl. Environ. Microbiol. 75:5037-5046.

Uchiumi, T., Ohwada, T., Itakura, M., Mitsui, H., Nukui, N., Dawadi, P., Kaneko, T., Tabata, S., Yokoyama, T., Tejima, K., Saeki, K., Omori, H., Hayashi, M., Maekawa, T., Sriprang, R., Murooka, Y., Tajima, S., Simomura, K., Nomura, M., Suzuki, A., Shimoda, Y., Sioya, K., Abe, M., and Minamisawa, K. 2004. Expression islands clustered on the symbiosis island of the Mesorhizobium loti genome. J. Bacteriol. 186:2439-2448.

Ventura, M., Kenny, J. G., Zhang, Z. D., Fitzgerald, G. F., and van Sinderen, D. 2005. The clpB gene of Bifidobacterium breve UCC 2003 Transcriptional analysis and first insights into stress induction. Microbiol.-SGM 151:2861-2872.

Wang, J., Song, J. J., Franklin, M. C., Kamtekar, C. S., Im,Y. J., Rho, S. H., Seong, I. S., Lee, C. S., Chung, C. H., and Eom, S. H. 2001. Crystal structures of the HsIVU peptidase-ATPase complex reveal an ATP-dependent proteolysis mechanism. Structure 9:177-184.

Weibezahn, J., Schlieker, C., Tessarz, P., Mogk, A., and Bukau, B. 2005. Novel insights into the mechanism of chaperone-assisted protein disaggregation. Biol. Chem. 386:739-744

Zahran, H. H. 1999. Rhizobium-legume symbiosis and nitrogen fixation under severe conditions and in an arid climate. Microbiol. Mol. Biol. Rev. 63:968-989.

Zhang, F., and Smith, D. L. 1996. Genistein accumulation in soybean (Glycine max L Merr) root systems under suboptimal root zone temperatures. J. Exp. Bot. 47:785-792.

Zolkiewski, M. 1999. ClpB cooperates with DnaK, DnaJ, and GrpE in suppressing protein aggregation-A novel multi-chaperone system from Escherichia coli. J. Biol. Chem. 274:28083-28086.

Zolkiewski, M., Kessel, M., Ginsburg, A., and Maurizi, M. R. 1999. Nucleotide-dependent oligomerization of ClpB from Escherichia coli. Protein Sci. 8:1899-1903.

\section{AUTHOR-RECOMMENDED INTERNET RESOURCE}

National Center for Biotechnology Information Mesorhizobium australicum WSM2073 webpage: www.ncbi.nlm.nih.gov/nuccore/354575234 